\title{
Recent studies of the urobilin problem ${ }^{1}$
}

\author{
C. J. WATSON ${ }^{2}$ \\ From the Department of Medicine, University of Minnesota Hospital, Minneapolis, Minn.
}

It is now almost a century since Jaffé $(1868,1869)$ described urobilin. It would manifestly be an imposition on your patience if I were to attempt any comprehensive treatment of the ensuing history of this topic, but I shall strive to bring together for you a few of what seem to me the more important milestones in their relation to recent studies. For reasons that will become apparent, the term urobilin, both on historical and clinical chemical grounds, is best applied to a group of closely related substances. Under ordinary circumstances the urobilin group is related mainly to destruction of the haemoglobin of circulating red cells. Other possible sources will be referred to later. Jaffé in 1868 was not in a position to relate his newly discovered urobilin to haemoglobin catabolism as at that time definite evidence was lacking that bile pigments were derived from haemoglobin. While Virchow (1847) had suspected that the 'haematoidin' which he found in old haemorrhages was identical with bilirubin, this was doubted by others, especially by Städeler (1864) who first crystallized bilirubin and named it. Actually it was not until 1923 that this question was settled by Hans Fischer and Reindel whose careful crystallographic comparison of haematoidin and bilirubin clearly established their identity. Long before this Tarchanoff, in 1874, had shown that haemoglobin given intravenously in dogs with bile fistulae results in proportional increase of bilirutin in the bile. It is now generally accepted that the conversion of haemoglobin to bilirubin is readily effected by a highly specific enzymatic activity $\mathrm{w}$ hich is $\mathrm{v}$ idespread but probably limited to certain tynes of cells, especially those of mesenchymal or retic.loendothelial type. Many other mammalian systems as, for example, that lining the gastrointestinal tract, do not elaborate this enzyme which has recently been partially purified by Nal a ima (1958). The primary activity in converting hremoglobin to bile pigment may be defined as an $o$ idative loss of the $\alpha$ methene bridge carbon atom of the haemoglobin protoporphyrin, a haemoglcbin-haptoglobin complex, being the specific substrat (Yamaguchi, Nakajima, and Yamaoka,

${ }^{1}$ The Thomas Young lecture given at St. George's Hospital Medical School, London, on 15 February 1962.

${ }^{2}$ Supported by a grant from the Research and Development Command, Sutg:cn General's Office, United States Army.
1961). Sjöstrand (1949) demonstrated that this is lost as $\mathrm{CO}$, an important observation not yet exploited to any extent by clinical investigators. It is intriguing that the opening of the porphyrin ring to form bile pigment involves only the $\alpha$ bridge carbon. A number of years ago Schwartz and I (Watson and Schwartz, 1942) converted the bilirubins from each of a series of human fistula biles to urobilinogen, thence to a crystalline urobilin, which was shown to be the same in all instances, i.e., 9, $\alpha$ in type. Gray, Nicholson, and Nicolaus (1958) at King's College Hospital, using a much more elegant and precise method depending on oxidation to monopyrrolic compounds, have recently shown that naturally occurring bile pigments are uniformly $9, \alpha$ in type. There are 15 possible protoporphyrin isomers, type 9 being one of several corresponding in configuration to the aetioporphyrin III series.

Biliverdin stands closest in structure to protoporphyrin and there is no reason to doubt, in accordance with Lemberg's (1955) emphasis, that it is the primary or mother bile pigment. It is readily reduced to bilirubin by mild agents such as dithionite or ascorbic acid; however, this reduction in vivo has been shown by Lemberg to be enzymatic and the enzyme 'biliverdin reductase' has recently been partially purified by Singleton and Laster (1961). The further conversion of bilirubin to mesobilirubin and the urobilinogen group requires more strenuous reduction in vitro and can only be achieved in part. As I shall discuss later, the reduction in vivo to mesobilirubin and beyond probably depends entirely on bacterial activity, quite in accord with the belief advanced by Maly $(1871,1872)$ only three years after Jaffé described urobilin. Maly reduced bilirubin partially with sodium amalgam, obtaining what he called 'hydrobilirubin', subsequently shown by others to represent a mixture exhibiting 'urobilin' characteristics, i.e., green fluorescence with zinc and an absorption band in the blue-green region of the spectrum.

It may now be desirable to bring together briefly the essential information on the composition of the urobilin group. Van Lair and Masius in 1871 described the faecal stercobilin, noting its similarity with Jaffé's urobilin, but leaving open the question of identity. It gradually became recognized, as a 
result of the work of Le Nobel (1887), Saillet (1897), and Neubauer (1903) that these substances in both urine and faeces were excreted mainly as colourless chromogens. In 1911 Hans Fischer carried Maly's amalgam reduction of bilirubin to completion and, employing the Ehrlich aldehyde reaction (1901) to follow concentration of the resulting colourless chromogen, succeeded in crystallizing a well-defined chemical individual which he eventually named mesobilirubinogen. Fischer and Meyer-Betz (1911) soon demonstrated that this was identical with a crystalline urobilinogen obtained from the urine in a case of hepatic cirrhosis. The question remained whether this was the only urobilinogen and whether identical with the stercobilinogen of the faeces. This was of practical as well as basic interest, especially in relation to quantitative estimation in the excreta, in the study of liver function, jaundice, and haemolytic disease.

From Jaffé and Van Lair and Masius onward, many unsuccessful attempts were made to crystallize urobilin from urine or stercobilin from faeces. The most detailed perhaps were those of Garrod and Hopkins (1896) and of Hopkins and Garrod (1898) and of Hans Fischer (1911), but there is little doubt that earlier workers, notably MacMunn and Thudichum, were keenly interested in this problem. Let me pause to pay tribute to the memory of Thudichum who was Lecturer in Natural Philosophy, later Professor of Chemistry in the old St. George or Grosvenor Place School of Medicine during the period 1855-63. I am the proud possessor of a first edition of his 'Pathology of the urine' (1858) which, accordingly, must have been written during his tenure in that school. As you well know, Thudichum is often spoken of as the 'father of brain chemistry' (Drabkin, 1958) but his contributions to the chemistry of human urine are in many ways just as notable. In 1858 he spoke of 'urohaematine' and 'uroerythrin', neither of which were well defined. In 1864 his classic paper 'Urochrome: the colouring matter of urine' appeared. This term superseded 'urohaematine' and has ever since designated the normal pigment complex of the urine. It seems reasonable to believe that his 'uroerythrin' included some fraction of the urinary 'urobilin' which Jaffé was not to describe until ten years later. Thudichum mentions that the largest amounts were noted in cases of liver disease and there is little doubt that these urines contained excessive urobilin. Nevertheless, he was well aware of the peculiar affinity of uroerythrin for amorphous urate, the socalled 'sedimentum latericium', which includes little or no urobilin. The exact origin and significance of uroerythrin are quite unknown to this day. In later years Thudichum (1897) emphasized that urobilin was not to be confused with urochrome although it is difficult to understand why he believed it was derived from urochrome.

The failure of Hopkins and Garrod and of Hans Fischer, as well as many others, to isolate a crystalline urobilin or stercobilin might well have discouraged further effort in this direction. But I must admit to a number of unsuccessful attempts of my own during the late twenties. In these I followed in the main the valuable procedure of Terwen in Amsterdam (1925) which in retrospect would have permitted crystallization with but slight additional purification. Becausz of previous failures on this score I first attempted, while in Hans Fischer's laboratory in $1930-32$, to isolate the principal Ehrlich reacting chromogen of human faeces in order to determine its identity or lack of identity with mesobilirubinogen. Despite the use of many alternative procedures and many kilograms of faeces, especially from individuals with haemolytic jaundice, this attempt was also unsuccessful. By good fortune, however, it led indirectly to the isolation of crystalline stercobilin (Watson, 1932a and b, 1933a and b, 1934, 1935a and b). This was first observed in a solution which had been set aside for several days because of its content of a violet substance later identified for the first time in the excreta as mesobiliviolin (Watson, 1932b; 1933a and b), which Fischer and Niemann (1924) had previously prepared by dehydrogenation of mesobilirubinogen. The stercobilin crystals first appeared as brown feathery masses, but on recrystallization from chloroform as orange-yellow prisms. These gave intense green fluorescence with alcoholic zinc acetate, and the characteristic urobilin type absorption band, maximum at about $492 \mathrm{~m} \mu$. It was now possible to show that this stercobilin differed from urobilin immediately derived by dehydrogenation of mesobilirubinogen. The colourless, Ehrlich-reacting stercobilinogen could not and has not yet been crystallized. Strenuous oxidation of mesobilirubinogen or its urobilin gave methyl ethyl maleininimide; that of stercobilin did not. The latter is strongly laevorotatory (Fischer, Halbach, and Stern, 1935), the former optically inactive. A suitable method was found for crystallization of the inactive or i-urobilin (Watson, 1935a and b) and this has recently been improved to permit direct preparation from bilirubin (Watson, 1953). Lemberg, Lockwood, and Wyndham (1938) first showed that the absorption band of $\mathrm{i}-\mathrm{U}$ differs slightly from that of stercobilin. It is interesting in this connexion that MacMunn $(1880 ; 1889)$ described at least two spectroscopically distinct urobilins, that in the bile differing from what he observed in the urine. Because of the crude spectrometry of his day, it cannot be determined whether 
MacMunn first distinguished l-stercobilin from i- or d-urobilin.

The latter or third member of the natural urobilin group to be crystallized was first isolated from infected fistula bile (Schwartz and Watson, 1942). Later this was obtained from the faeces of patients who had recently received broad-spectrum antibiotics, especially tetracyclin (Sborov et al., 1951; Watson and Lowry, 1956). This urobilin was strongly dextro-rotatory in contrast to stercobilin and iurobilin (Watson and Lowry, 1956). Its absorption spectrum was identical with that of $i-U$. The infra-red spectrum was essentially the same, differing considerably from that of 1-stercobilin (Watson and Lowry, 1956). These compounds are not isomers and this is perhaps best emphasized by the number of hydrogens in their molecules, thus d-U $\left(\mathrm{H}_{42}\right)$, i-U $\left(\mathrm{H}_{42}\right)$, and 1-S $\left(\mathrm{H}_{46}\right)$, the corresponding chromogens, each having two more. Gray and Nicholson (1958) have prepared a d-U $\left(\mathrm{H}_{40}\right)$ and a racemic form of d-U $\left(\mathrm{H}_{40}\right)$. It is not yet known whether either of these occur in nature. Certain recent observations, to be described elsewhere, suggest that the racemic d-U may on occasion be formed in nature.

The structure of i-U was established by Siedel and Meier's synthesis (1936) as well as by the earlier synthesis of the parent chromogen by Fischer and Adler (1931). There is still uncertainty about the structures of $\mathrm{d}-\mathrm{U}$ and $\mathrm{I}-\mathrm{S}$, and $\mathrm{I}$ refer you for formulation and supporting data to the papers of Gray and Nicholson (1957b, 1958b), Siedel (1957), and Gray, Kulczycka, and Nicholson (1961). Perhaps the most interesting question in this respect, at least from a biochemical point of view (see Fig. 1) is whether d-U $\left(\mathrm{H}_{40}\right)$ is an isomer of mesobilirubin in which both vinyl $\left(\mathrm{CH}=\mathrm{CH}_{2}\right)$ groups of bilirubin have been reduced to ethyl groups (Siedel, 1957) or a monovinyl compound for which Gray and Nicholson (1958b) have marshalled important evidence, especially the amount of methyl ethyl maleinimid expected in relation to a monoethyl compound. The formation of $\mathrm{d}-\mathrm{U}$ by the bacterial reduction of bilirubin, to which I shall refer later, would thus involve reduction of one of the vinyl groups of bilirubin without mesobilirubin as an intermediary, as it is in the case of $\mathrm{i}-\mathrm{U}$ and l-S. According to this, d-U would presumably be derived from dihydrobilirubin, already a monovinyl compound. This, however, would not exclude a reduction of $d-$ to $i-$ and, in fact, this has been shown to occur $w$ ith reducing agents such as sodium amalgam and ferrous hydroxide, or with suitable bacterial cultures, as I shall mention presently.

The remarkable similarity, indeed the almost complete identity of the absorption spectra of the $\mathrm{d}$ - and $\mathrm{i}$ - forms is of considerable interest if $\mathrm{d}$ - is in fact a monovinyl compound. While the infra-red spectrum fails to show the characteristic vinyl absorption at $10.08 \mu$, prominent in bilirubin and biliverdin, absent in mesobilirubin, this cannot be said to exclude the monovinyl formula. In the interval since the above was written additional significant information has been obtained which requires mention.

1 Mesobilirubin has been converted to d-urobilin in vitro by the human faecal flora. This constitutes strong evidence against a monovinyl formulation of d-U (Fig. 1). (Watson and Weimer, in press.)

2 Bilirubin has been reduced catalytically to $( \pm)$ stercobilinogen, and the corresponding stercobilin has been crystallized (Kay, Weimer, and Watson, in press).

It is best at this point to discuss briefly a means of determining the ratio of naturally occurring $\mathrm{d}-, \mathrm{i}$ - and 1 - forms, as in bile or excreta. This was of particular moment in view of a number of claims that the proportion of $\mathrm{i}$-/1- forms in the urine was highly significant in relation to parenchymal liver disease, as contrasted with haemolytic disease or the normal state (Stich, 1946 and 1948; Baumgärtel, 1950; Rudolph, 1952; Maier and Schwarz, 1953). These assertions were based on a qualitative $\mathrm{FeCl}_{3}$ oxidation test with disregard of the possible presence or proportion of $d-U$, and with the assumption that the appearance of a violet, purple, or blue colour indicated $\mathrm{i}$ - and little or no 1 -. As a matter of fact, small proportions of $\mathrm{i}-$, as little as $10-20 \%$, often give a fairly intense purple or lavender colour, and may thus be misleading as a qualitative test. Fischer and Niemann (1924) first described the formation of mesobiliviolin by $\mathrm{FeCl}_{3}$ oxidation of mesobilirubinogen. Stercobilin or stercobilinogen does not yield mesobiliviolin with similar treatment. At one time I (1950) stated that it did but I am convinced now that this was due to admixture of small amounts of $\mathrm{i}-\mathrm{U}$, and that Lemberg and Legge (1949) were correct in emphasizing the sharp distinction of the two forms on this basis. Legge (1949) proposed a spectrophotometric method for quantitative distinction, depending on absorption at $490 \mathrm{~m} \mu$ (1-S) and $560 \mathrm{~m} \mu$ (mesobiliviolin). This also disregarded d-U, nor did it take into account the glaucobilin (mesobiliverdin) formed from both $\mathrm{i}$ - and $\mathrm{d}-\mathrm{U}$, maximal absorption $650 \mathrm{~m} \mu$. We (Watson and Weimer, 1959) have adapted the methods of Fischer-Niemann and Legge to a standard procedure which is highly reproducible, permitting approximate determination of the ratio of the three forms, d-, i-, and l-, in a given sample. This depends on the observation that under the conditions employed, $\mathrm{d}-\mathrm{U}$ is converted first to mesobiliviolin (or its red isomer, mesobilirhodin) and this in turn to glaucobilin, while the mesobiliviolin from $\mathrm{i}-\mathrm{U}$ does not behave as a single entity in 
this respect, about half being converted to glaucobilin, the remainder relatively a stable violinoid compound with absorption unchanged at $560 \mathrm{~m} \mu$ (Watson, Weimer, and Hawkinson, 1960). Determination of the ratios of absorption $\frac{492}{560+650}$ and 560 $\frac{560}{650}$ permits an approximate estimation of the proportion of d-, i-, and l- represented (Watson and Weimer, 1959).

When d-urobilin was first discovered it was regarded as an expression of abnormal bacterial activity, but it has now been found in the excreta of some individuals who have not received broad-spectrum antibiotics (Watson, 1956; Gray and Nicholson, 1958b; Watson and Weimer, 1959). Perhaps more important, the contents of the caecum obtained at necropsy on previously healthy cases of vascular or traumatic sudden death have at times been found to have mainly, or entirely, d-U (Watson, 1958; Watson and Weimer, 1959). In some of the same cases the sigmoid faeces had variable mixtures of $\mathrm{i}-$ and $\mathrm{1}-$; in others, however, the ratio was essentially the same as in the caecum, and in certain instances even the caecum contained $\mathrm{i}$ - and 1 -, or entirely 1-. In general the findings were in best accord with a concept of progressive reduction of variable rate in the caecum and across the colon, in some instances being completed in the caecum; that is, entirely to $1-$, in others only the d-stage being reached in the caecum, with conversion to $\mathrm{i}$ - and $\mathrm{l}$ - across the colon. This concept agrees with the finding, in two cases of haemolytic anaemia without history of antibiotics, that the urine contained only or mainly $\mathrm{d}-\mathrm{U}$, the faeces mainly $\mathrm{i}$ - and $1-$. In a third case the urine contained $90 \% \mathrm{i}$-, $10 \% \mathrm{l}$-, the faeces at the same date $20 \% \mathrm{i}-, 80 \% \mathrm{l}$ - (Table I). The latter findings are also

\section{TABLE I}

D-, I-, AND L- FORMS IN URINE AND FAECES IN HAEMOLYTIC ANAEMIA

\begin{tabular}{|c|c|c|c|c|}
\hline Case & & $d-(\%)$ & $i-(\%)$ & $l-(\%)$ \\
\hline 1 & $\begin{array}{l}\text { Faeces } \\
\text { Urine }\end{array}$ & 100 & 80 & 20 \\
\hline 2 & $\begin{array}{l}\text { Faeces } \\
\text { Urine }\end{array}$ & $\begin{array}{l}40 \\
75\end{array}$ & $\begin{array}{l}40 \\
25\end{array}$ & 20 \\
\hline 3 & $\begin{array}{l}\text { Faeces } \\
\text { Urine }\end{array}$ & & $\begin{array}{l}20 \\
90\end{array}$ & $\begin{array}{l}80 \\
10\end{array}$ \\
\hline
\end{tabular}

in accord with the concept of progressive reduction across the colon, assuming a greater absorption from the caecum and right half of the colon and correspondingly greater enterohepatic circulation of less reduced form. Contrary to statements in the literature we have found that the normal urine often con- tains $\mathrm{i}-$ as well as $1-$, and sometimes mainly $\mathrm{d}-$. We have not found any evidence of a characteristic pattern in disease states, such as postulated by others, i.e., a preponderance of $1-$ in haemolytic disease. or of $\mathrm{i}$ - in liver disease (Table II).

Let me now comment briefly on some additional interesting aspects of the reduction of bilirubin by the intestinal bacterial flora. As I mentioned earlier, the enterogenous theory of urobilin formation was first advanced by Maly in 1871 . It was strongly supported by Friedrich von Müller's well-known experiment in which urobilin-free swine bile was fed to a patient with complete common duct obstruction due to cancer. This patient's excreta were essentially free of urobilin as is characteristic of this form of biliary

\section{TABLE II}

SOME VARIATIONS IN COMPOSITION OF URINARY UROBILIN GROUP IN HEALTH AND DISEASE

\begin{tabular}{|c|c|c|c|}
\hline No. & Diagnosis & $\begin{array}{l}\text { Pattern after } \\
\mathrm{FeCl}_{3} \text { Oxidation }\end{array}$ & $\begin{array}{l}\text { Previous } \\
\text { Chemotherapy }\end{array}$ \\
\hline 1 & Normal & d- $>$ i- $>1-$ & Eight months before \\
\hline 2 & None & $\mathrm{i}->1-$ & None \\
\hline 3 & None & $\mathrm{i}-=1-$ & None \\
\hline 4 & None & $1->\mathrm{i}-$ & None \\
\hline 5 & Cirrhosis & d- only & Tetracycline \\
\hline 6 & Cirrhosis & $1-=\mathrm{i}-$ & None \\
\hline 7 & Hepatitis & $1-=\mathrm{i}-$ & None \\
\hline 8 & Hepatitis & $1->\mathrm{i}-$ & None \\
\hline 9 & Hepatitis & d- only & None \\
\hline 10 & Haemolytic anaemia & d- $>$ i- & None \\
\hline 11 & Haemolytic anaemia & $\mathrm{i}->1-$ & None \\
\hline 12 & Haemolytic anaemia & $1->\mathrm{i}-$ & None \\
\hline
\end{tabular}

obstruction. Two days after the bile was fed urobilin appeared in the urine, and on the next day in the faeces, persisted for three days then disappeared. This experiment was carried out in 1887; Paul Ehrlich first described the urinary aldehyde reaction in 1901 and its relationship to urobilinogen was pointed out by Neubauer, in Müller's clinic, in 1903. It is evident that Müller could not have used the Ehrlich reaction at the time of his experiment. Walzel and Weltmann (1924) reported many years later that swine bile often exhibits a positive Ehrlich reaction due to urobilinogen, and on this basis doubted the validity of Müller's experiment in establishing the enterogenous theory. I have confirmed Walzel and Weltmann's observation. The amounts are relatively small, but apart from this the time relationships indicate that the urobilin which Müller observed in the urine two to three days after feeding bile had indeed been formed from the bile bilirubin in the colon. When urobilinogen is administered in the same manner it appears in the urine, if at all, within 24 hours, due to absorption from the small intestine. Recently we repeated the Müller experiment using urobilin- and urobilinogenfree human bile, with a resultant plentiful formation 
and transitory excretion of urobilinogen in the faeces (Gilbertsen and Watson, 1962). This was in contrast to earlier and recent experiments with pure bilirubin in which little or no urobilinogen formation was observed (Fischer and Meyer-Betz, 1911; Fromholdt and Nersessoff, 1912; Fischer and Libowitzky, 1939; Bungenberg de Jong, 1942; Watson, 1938). The basis of this, which by no means vitiates the enterogenous concept, as has been suggested, will be considered presently.

The first decisive reduction of bilirubin to urobilinogen by bacteria in vitro was reported almost simultaneously in 1922 by Passini and Czaczkes (1923) and by Kämmerer and Miller (1922). The former stated that a pure strain of Clostridium was effective, the latter that a symbiotic activity of an anaerobe (B. purificus) and $E$. coli was essential to the conversion. This was later championed by Baumgärtel (1950) who believed, however, that bacterial re- duction led only to l-stercobilin, not the i-form, a point that $I$ shall touch on in a moment. The most important work in this relationship has recently been reported by Gustafsson and Lanke (1960). They found that the faeces of germ-free rats is entirely lacking in urobilin(ogen) but a Clostridium species from normal rat faeces, when fed to germfree rats, readily produced urobilinogen in considerable amount. The production was enhanced if $E$. coli was also given. We had previously studied the activity of a mixed, normal human faecal flora in reducing free as contrasted with conjugated bilirubin (glucuronide) to urobilinogen (Watson, Campbell, and Lowry, 1958). In these experiments we were especially interested in the resulting proportion of the d-, i-, and l- forms. It was found that conjugated bilirubin was reduced more efficiently; both free and conjugated forms gave rise to variable mixtures of $d$-, $\mathrm{i}$-, and 1-. The marked formation of $\mathrm{d}-\mathrm{U}$ with several

FIG. 1. Structural formulae of bilirubin and important natural derivatives, as based on syntheses or postulated.
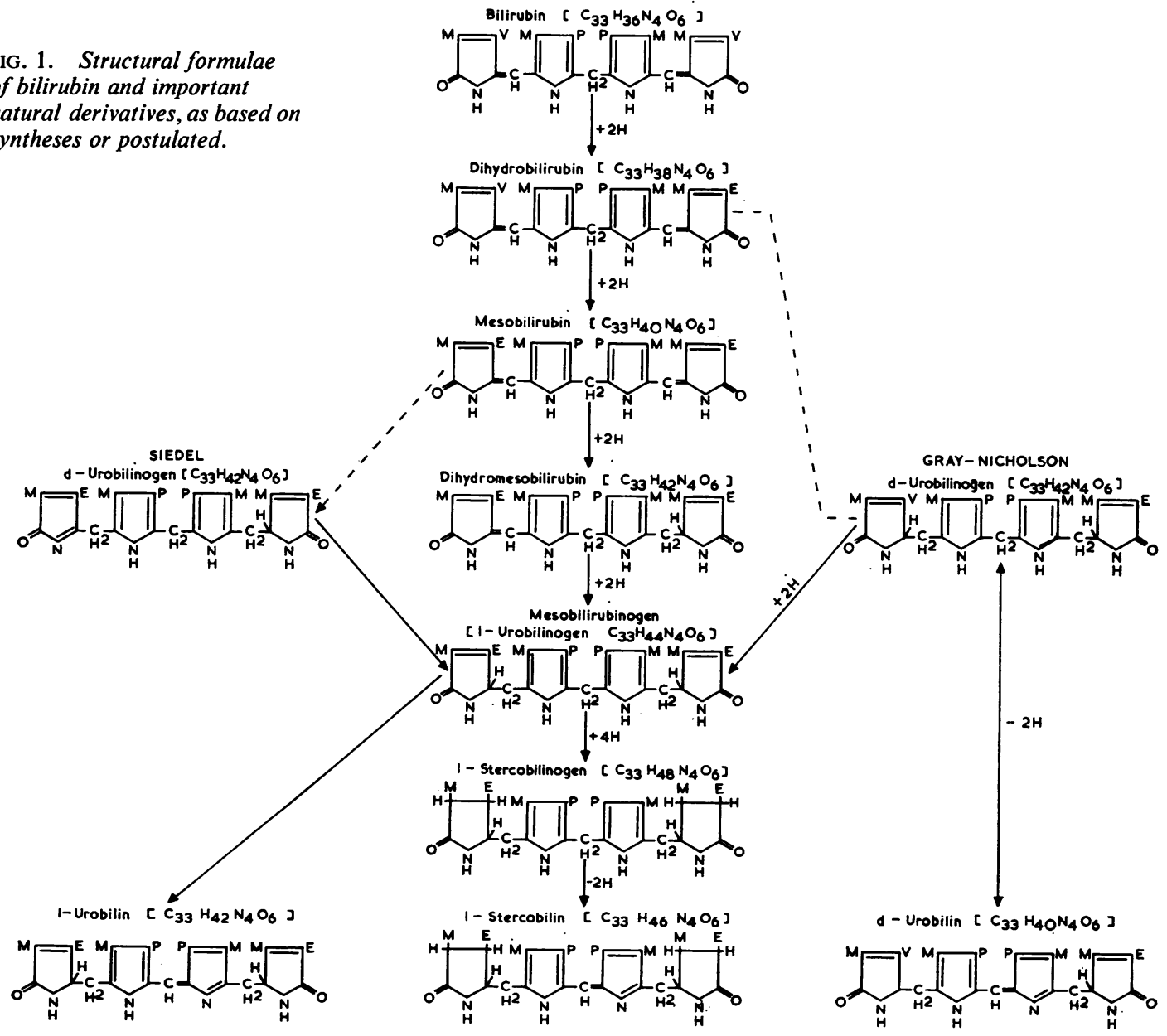
samples of normal faecal flora was of particular interest. We were therefore grateful to Professor Gustafsson for the opportunity to carry out similar studies with his rat Clostridium species. We found that it was more difficult to obtain the luxuriant growth which is best correlated with urobilinogen formation by the mixed human faecal flora. Not a few experiments were complete failures and the basis for this was not always clear. In the successful runs the reduction of conjugated bilirubin was invariably more efficient than that of the free form. It was of no little interest to find that a considerable proportion of the urobilinogen group formed was still conjugated, behaving as a labile ester glucuronide. Noro (1951) and the Kaháns (1959) have observed that a fraction of the urinary urobilin is a conjugate of some type. It was surprising, however, that formation of $d$ - Uwas quite exceptional in the successful experiments with Clostridia as compared with its relatively frequent appearance with a mixed human flora. Both i- and 1were readily produced by the Clostridium alone and it was capable, though inconsistently, of reducing dto $\mathrm{i}-$ and $\mathrm{i}-$ to $1-$. No qualitative or quantitative variation was noted when $E$. coli was grown simultaneously, in contrast to the apparent enhancement which Gustafsson noted in the rat in vivo. The chief difference from the normal mixed human flora was in the usual but not invariable failure to form d-U. It is possible that the Clostridium, at least under the usual conditions of growth, in vitro, carries the hydrogenation over mesobilirubin and dihydromesobilirubin to i-urobilinogen, without formation of d-urobilinogen as intermediary, regardless of whether the latter is a diethyl or monovinyl compound (Fig. 1). It is quite possible that relatively minor environmental circumstances determine the pathway, and this may also be true for the 으 human faecal flora, as in a number of experiments $\Rightarrow$ only i- and l- were observed although in these d-U $\stackrel{\vec{F}}{\rightarrow}$ might have been present in the earlier stages of 0 reduction, rapidly converted to $\mathrm{i}-\mathrm{U}$. Evidence of this rapid conversion was noted in experiments in which

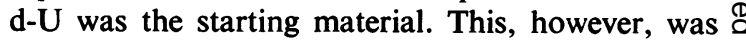
not seen with the rat Clostridium; in fact, the con- क version was too slow to support the possibility that $\vec{\circ}$ d- was being formed and rapidly converted to i-.

All of these recent observations on the bacterial $\vec{\omega}$ reduction of bilirubin have particular significance for the longstanding question of enterogenous vs. ? hepatogenous formation of the urobilin group. The $\vec{\sigma}$ Friedrich Müller experiment and the later elegant $\overrightarrow{.}$ studies of McMaster and Elman (1925, 1926, 1927) had appeared to establish the former quite conclusively and to exclude the latter concept. McMaster showed that total bile fistula dogs, if prevented from licking up any of their bile, formed no urobilin, nor did they do so after liver injury or biliary obstruction. Urobilin formation was associated only with infection of the biliary tract or return of bile to the intestine. Ugarte (unpublished observations), working in the author's laboratory, took advantage of Stadelmann's early observation (1891) that urobilinuria is prominent in dogs with toluylenediamine jaundice. Ugarte found that after construction of a bile renal fistula and renewed administration of the drug the same animals again develop jaundice but now without urobilin appearing in the urine (Fig. 2).

Despite many valid obstacles, the hepatogenous concept was reintroduced by Baumgärtel (1950) as part of a dichotomous theory which he and a number

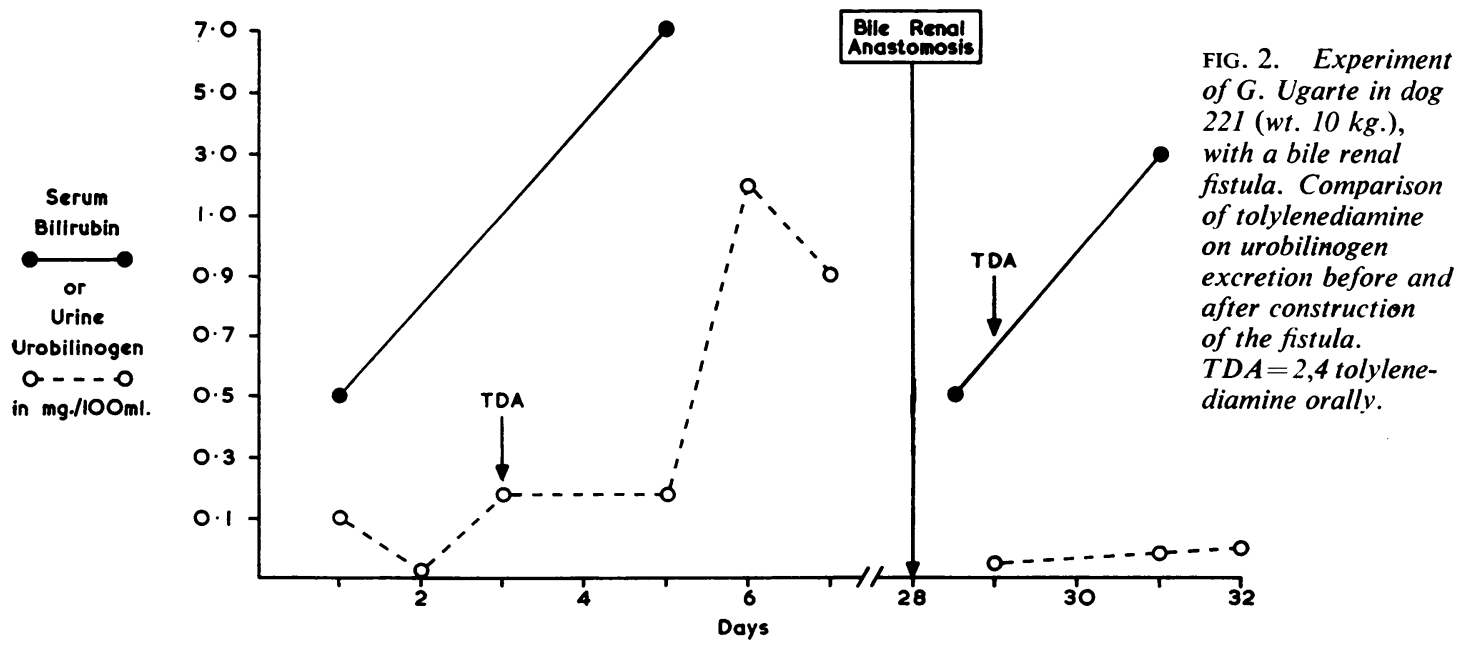

FIG. 2. Experiment in dog arison of tolylenediamine on urobilinogen after construction of the fistula. $T D A=2,4$ tolylene diamine orally. 
of others (Stich, 1946 and 1948; Rudolph, 1952; Maier and Schwarz, 1953) have urged.

A few comments are needed on some of the principal facets of the Baumgärtel concept.

1 This requires that i-urobilinogen be not found in the faeces, and that it be not formed by faecal bacteria, nor converted by these organisms to l-stercobilinogen. As noted earlier, $\mathrm{i}-\mathrm{U}$ is readily formed both by a mixed faecal flora and a pure strain of Clostridium; the bacterial conversion of $\mathrm{i}$ - to 1 - has been demonstrated, more recently in an experiment with Lowry, Ziegler, Cardinal, and Watson (1954) in which $\mathrm{N}^{15}$ labelled $\mathrm{i}-\mathrm{U}$ was employed. Moreover, our earlier failures to isolate crystalline mesobilirubinogen from faeces have in more recent years been overcome (Watson, 1950; Watson, Lowry, Collins, Graham, and Ziegler, 1954). Also, the differential spectrophotometric method which I mentioned earlier has shown that this chromogen is present in varying though usually minor proportion with the l-form.

2 The finding of Gustafsson and Lanke (1960) that normal germ-free rats form no urobilin is in accord with the long-recognized fact that urobilin formation is lacking in early post-natal life of the human infant and does not appear until the faecal flora becomes well established. The Baumgärtel concept requires some concomitant liver injury or bile stasis for the postulated hepatic formation of i-urobilinogen. Professor Gustafsson (personal communication) has recently provided this as well in the observation that $\mathrm{CCl}_{4}$ poisoning in germ-free rats does not induce urobilinogen formation, though normal rats with the same liver injury regularly exhibit urobilinuria. The effect of broad-spectrum antibiotics on urobilinogen group formation also deserves emphasis in this connexion. We observed that at the outset of such effect, the reduction of bilirubin is largely abolished (Sborov, Jay, and Watson, 1951; Watson et al., 1954). For several days the faeces contain mainly bilirubin. Urobilinogen formation returns when the antibiotic is discontinued and more slowly when it is continued but is now entirely represented by the $\mathrm{d}$-form. At this time d-U will also be found in the urine, especially in cases of liver disease. This preponderance will persist as long as the antibiotic is continued. On discontinuance the d-U disappears and is for a time replaced by the i-form, which may readily be crystallized, either as mesobilirubinogen or i-urobilin. Later the normal dominance of 1-stercobilin returns. It is obvious that such a sequence is scarcely compatible with the Baumgärtel dichotomous concept.

3 It is alleged as a part of this concept that i-urobilinogen formation is enhanced by liver injury, especially in relation to intrahepatic bile stasis; that its presence in the urine is pathological, but that as the serum bilirubin level rises, the bilirubin inhibit the hepatic dehydrogenase activity, thus explaining the disappearance of urobilin(ogen) from the urine in cases of complete biliary obstruction or exclusion of bile due to liver disease. As noted in the foregoing, this is not supported by numerous experiments in animals with bile fistula, nor by the repeated finding of $\mathrm{i}-\mathrm{U}$ in normal urine. Nor is there any evidence that conjugated bilirubin, which would necessarily be implicated in relation to biliary obstruction, is inhibitory to any enzyme system.

For the final part of my talk, I wish to discuss briefly the perplexing problem of the variable relation of the urobilinogen group to haeme metabolism, both destruction and synthesis. There are two opposing aspects in the consideration of this problem: 1 The partial, variable derivation of the total urobilinogen from sources other than the destroyed haemoglobin of mature circulating erythrocytes; this tends to enlarge the value for faecal urobilinogen unduly insofar as a measurement of ordinary haemoglobin catabolism is concerned. 2 The variable discrepancy between the amount of urobilinogen excreted as compared with that to be anticipated on the basis of total circulating haemoglobin and red cell life span; as I shall presently note, the amount excreted is generally too small even under normal circumstances. At times, especially in certain anaemias, the discrepancy is great.

The relative ease of serial isolation of crystalline stercobilin from the faeces as contrasted with that of bilirubin from duodenal contents induced London, West, Shemin, and Rittenberg (1950) to study the $\mathrm{N}^{15}$ content of the faecal stercobilin after the administration of $\mathrm{N}^{15}$ glycine. In a normal individual, London et al. found that while most of the $\mathrm{N}^{15}$ appeared in the stercobilin at a time corresponding with the destruction of mature circulating red cells, about $11 \%$ was represented in an earlier, smaller peak. It is evident that this 'early peak' would contribute to the faecal urobilinogen value proportionately without representing ordinary haemoglobin catabolism. Gray and Scott (1958) have shown in beautiful fashion that this early peak may be significantly accentuated by stimulation of haemopoiesis, as by sufficient blood letting. On this basis they designate it as the 'haemopoietic peak'. Nevertheless, it seems likely that the basis for it may vary under different circumstances, as James and Abbott (1961a) have recently observed prominent early $\mathbf{N}^{15}$ stercobilin peaks in two cases of a plastic anaemia in which normoblasts were almost entirely lacking in the bone marrow. The significance of this highly intriguing observation remains to be clarified. Obviously, it poses the question whether in this situation the early 
peak may be related to non-haemoglobin haemes such as those of the cytochromes, catalase, peroxidase, or even myohaemoglobin. It is conceivable that chronic anaemia might augment the turnover of any of these possible sources of bile pigment.

In a case of pernicious anaemia in relapse, London and West (1950) observed that the early peak comprised $60 \%$ of the total $\mathrm{N}^{15}$ in stercobilin. This was far more than could be accounted for by the mild increase of haemolytic activity in the same case, and confirmed earlier views, as discussed elsewhere (Watson, 1956), that much of the faecal urobilinogen in this disease is from sources other than destroyed circulating haemoglobin. I was impressed many years ago by the observation that the faecal urobilinogen in pernicious anaemia is usually much greater than would be anticipated from the decline of circulating haemoglobin and lack of reticulocyte increase in the same period (Watson and Jones, 1936). It would appear reasonable that because of the megaloblastic arrest, together with the relatively early appearance of haemoglobin in the cytoplasm of megaloblasts, there may actually be excretion of haemoglobin and rapid conversion to bilirubin, or possibly an intracellular conversion and excretion of bile pigment. Jedlicka (1930) many years ago advanced a somewhat similar hypothesis.

In ordinary haemolytic anaemias such as familial haemolytic disease, the correspondence between the amount of faecal urobilinogen and rate of haemoglobin destruction is usually quite close, as observed by my colleague, Dr. Paul Hagen (Hagen and MacDonald, 1954). Nevertheless, the more recent studies of James and Abbott (1959) indicate that variable but considerable fractions of the faecal urobilinogen belong to the 'haemopoietic' peak,

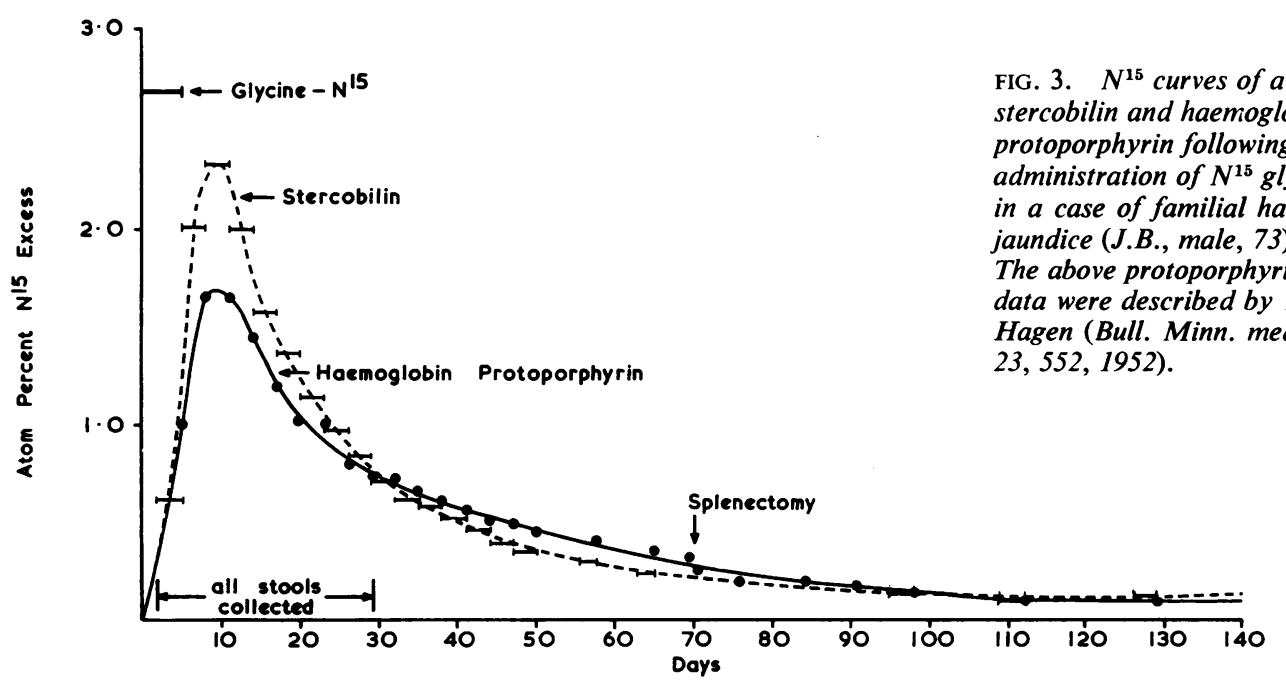

rather than being derived from mature red cell destruction. Thus the correspondence may often으 be more apparent than real. It is seen in Fig. $3 \vec{\Rightarrow}$. that in frank haemolytic anaemia the separation of an 'early' or 'haemopoietic' peak from one repre-을 sentative of destruction of circulating red cells is $\overline{\bar{c}}$ hardly possible. It is characteristic of haemolytic $\frac{\text { }}{\widetilde{D}}$ anaemia that the $\mathrm{N}^{15}$ (or $\mathrm{C}^{14}$ ) curve of stercobilin, $\varrho$ after administration of labelled glycine, is quite similar to that of the protoporphyrin of circulating $\vec{\theta}$ haemoglobin.

In addition, there are certain rare cases of what $\vec{\omega}$ Israels, Suderman, and Ritzmann (1959) have? designated as a primary 'shunt hyperbilirubinaemia'? in which, despite a superficial resemblance to haemo- $\vec{\sigma}$ lytic anaemia, the jaundice and large amounts of faecal urobilinogen are not explained by destruction $\vec{\circ}$ of mature circulating erythrocytes. Israels and? Zipursky (1962) have recently shown in decisive ${ }_{C}^{-}$ fashion, by means of $\mathrm{C}^{14}$ glycine, that about $82 \%$ of the faecal stercobilin is represented by the early peak, with a normal plateau for the haeme of the circulating erythrocytes. We are presently engaged in $\vec{\bullet}$ studying our first recognized case of this fascinating disease in a young man of 35 . He presents a mild hypochromic anaemia without iron deficiency,o associated with considerable retention jaundice, large amounts of faecal urobilinogen, reticulocytosis, and normoblastic hyperplasia in the bone marrow. This $\frac{\AA}{\mathbb{Q}}$ might seem adequate evidence of haemolytic $\varrho$ anaemia, but the $\mathrm{Cr}^{51} \mathrm{~T} \frac{1}{2}$ is normal, the spleen is not $\overrightarrow{\overrightarrow{0}}$ enlarged, the erythrocyte porphyrins are at a low normal level. An $\mathrm{N}^{15}$ glycine study is still in progress but even thus far the data clearly confirm an unusual derivation of bile pigment. The various features in this remarkable case will be described in detail else- 
TABLE III

EXAMPLE OF USUAL NORMAL DISCREPANCY BETWEEN BILE BILIRUBIN AND FAECAL UROBILINOGEN

\begin{tabular}{|c|c|}
\hline $\begin{array}{l}\text { Bile bilirubin (calculated per day } \\
\text { for a } 70 \mathrm{~kg} \text {. man) }\end{array}$ & $\begin{array}{l}220 \text { mg. (based on } 120 \text { days' life } \\
\text { span) }\end{array}$ \\
\hline $\begin{array}{l}\text { Observed in a case of total bile } \\
\text { fistula (female, } 85 \mathrm{~kg} \text {.) }\end{array}$ & $\begin{array}{c}242 \\
26(11 \%=\text { 'early peak' imma- } \\
\text { ture circulating R.B.C.s })\end{array}$ \\
\hline $\begin{array}{l}\text { Faecal urobilinogen/day (average } \\
\text { normal) } \\
\text { Faecal bilirubin/day (average normal) }\end{array}$ & $\begin{array}{l}216 \mathrm{mg} \text {. } \\
150 \\
10\end{array}$ \\
\hline $\begin{array}{l}\text { Total } \\
\text { Less } 11 \%\end{array}$ & $\begin{array}{r}160 \\
17\end{array}$ \\
\hline $\begin{array}{l}\text { Discrepancy } \\
\text { Mesobilifuscin (range) }\end{array}$ & $\begin{array}{l}143 \\
73 \mathrm{mg} . / \text { day } \\
8 \cdot 2-14 \mathrm{mg} . / \mathrm{day}\end{array}$ \\
\hline
\end{tabular}

where. They point to an abnormal process, perhaps actually in the normoblasts, in which bile pigment is being formed and excreted in large amount without being derived from the haemoglobin of circulating red cells. The haemoglobin deficiency and relative paucity of free erythrocyte porphyrins are in accord with such a concept.

Quite the opposite situation holds in the normal individual where the total urobilinogen fails by significant amounts to correspond with the values anticipated in relation to the total circulating haemoglobin for a life span for the erythrocytes of 120 days (Table III).

A similar or even greater deficit has been observed in not a few cases of anaemia other than pernicious or haemolytic types. The basis for this is not yet clear but certain revealing facts have emerged from our studies. For one thing, the deficit is clearly not explicable on the basis of dipyrryl compounds such as 'pentdyopent' (Bingold and Stich, 1954) or mesobilifuscin (Siedel, Pölnitz, and Eisenreich, 1947; Siedel, Stich, and Eisenreich, 1948), as has been suggested. The former, initially believed to represent schism of haeme by the kidney, is probably an artifact derived by oxidative schism of bilirubin or urobilin in the kidney or urinary tract. The amount is small and inconsequential, and this substance, which is excreted as a colourless chromogen, has not been found in the faeces. The faecal 'mesobilifuscin' group is of much more interest, but again the amount is far too small to explain the deficit in which we are interested; furthermore, Gilbertsen et al. (1959) have shown that at least in the normal individual most of the mesobilifuscin is of anabolic rather than catabolic origin, exhibiting an early $\mathrm{N}^{15}$ peak but essentially no rise at the time of destruction of mature circulating red cells. We have obtained information of much interest, with respect to the deficit, in an unusual case of hyporegenerative anaemia in which the faecal urobilinogen level was consistently very low, in the range of 20 to $30 \mathrm{mg}$./ day at a haemoglobin level of 9 to $10 \mathrm{~g} . \%$ (Gilbertsen and Watson, 1962). Calculated in relation to the total circulating haemoglobin, the amount would have corresponded to a red cell life span of over 400 days, yet the $\mathrm{Cr}^{51} \mathrm{~T} \frac{1}{2}$ was 27 days, as expected for a normal life span of 120 days. This individual quite clearly disposed of bilirubin or urobilinogen in a remarkably abnormal manner. The following additional facts have been ascertained and are described in detail in a separate communication (Gilbertsen and Watson, 1962).

1 Bilirubin given intravenously in fairly large amount was unaccounted for as faecal or urinary urobilinogen or mesobilifuscin, in contrast to a normal control subject in whom the anticipated increase of urobilinogen was observed. The same was true of conjugated bilirubin (glucuronide) given through a duodenal tube.

2 The patient's bile bilirubin was entirely conjugated and remained conjugated in its passage through the small intestine, although a progressive, marked decrease in concentration was observed; whether this was due to dilution or reabsorption could not be determined (see below).

3 Mesobilirubinogen (i-urobilinogen), given in solution through an inlying intestinal tube, was entirely recovered in the faeces, though in part as 1-stercobilinogen, as might be anticipated. In this instance at least there was no evidence of an enterohepatic circulation, such as we have observed in experiments in other subjects.

From these observations it appears likely that the striking disappearance of bilirubin in this case was related in some way to intestinal absorption. Despite many earlier reports that bilirubin is not absorbed, Lester, Ostrow, and Schmid (1961) have recently demonstrated that $\mathrm{C}^{\mathbf{1 4}}$ bilirubin, administered either as the free or conjugated form, was readily absorbed from the rat intestine, soon appearing in the bile. Stimulated by this observation, my associate, Dr. Gilbertsen, has given $\mathrm{N}^{15}$ bilirubin to an individual with a bile fistula, noting its prompt appearance in the bile (Gilbertsen, Bossenmaier, and Cardinal, 1962). It has not been shown in the human, nor for that matter, in any species, that conjugated bilirubin is absorbed as such.

As I have noted, the demonstrable bilirubin along the small intestine in the patient with refractory anaemia was entirely conjugated in behaviour, the concentration in the intestinal contents rapidly diminishing with increasing distance from the duodenum. It was at first thought that this simply 
represented dilution, but it is quite possible that the conjugate was being hydrolyzed, the resulting free bilirubin then quickly absorbed. Since unaccounted for in a later period, a conversion to some unrecognizable compound in the liver would have to be postulated, and this is by no means established. Nevertheless, it is possible that variable fractions of the conjugated bilirubin of the bile, even under normal circumstances, are hydrolyzed, thus permitting absorption of the free non-polar bilirubin, possibly in association with fat, the absorbed fraction being disposed of in some as yet undetermined manner.

In speaking of conjugated bilirubin I have been thinking, of course, of the ester glucuronide, as first demonstrated by Lathe and co-workers (Billing and Lathe, 1956), and Schmid (1956). This is relatively very labile, especially to alkali and heat. Isselbacher and McCarthy (1959) have described an alkali stable bilirubin sulphate in the bile of humans and rats. This might be expected to be reduced as the conjugate and to appear in the faeces as a urobilinogen sulphate, polar in behaviour, and not extractable by ethyl acetate which extracts free urobilinogen efficiently either from faeces or urine. If the faeces contained significant amounts of a urobilinogen sulphate, a proportionate deficit in ethyl acetate extractable as compared with direct Ehrlich values on the filtrates used in the quantitative method, would be expected, but in fact, the values are essentially the same. Apart from this, we (Gregory and Watson, 1962) have not been able to confirm the finding that human bile contains a bilirubin sulphate, nor has it been demonstrable in dog bile. After giving inorganic $S_{35}$ intravenously, the radioactivity was regularly separated completely from the bilirubin, both by washing on zinc hydroxide gel and by two-dimensional paper chromatography. Using the same methods we have, however, confirmed that the rat conjugates a minor fraction of the bilirubin with sulphate as noted also by Schoenfield, Bollman, and Hoffman (1962).

I mentioned earlier that Gustafsson's Clostridia reduce bilirubin glucuronide in vitro to a corresponding conjugate of urobilinogen. We have repeatedly sought the glucuronide conjugate in fresh human faeces, in a manner designed to avoid hydrolysis, but thus far it has not been observed, and it may be assumed tentatively that it is completely hydrolyzed in its transit through the colon.

In conclusion I believe I may have given you more of the urobilin story than one might fairly be expected to listen to, at least in one sitting. Let me thank you for your kind attention and assure you again of my sincere appreciation and gratitude for the honour of being entrusted with the Thomas Young memorial lecture.

\section{REFERENCES}

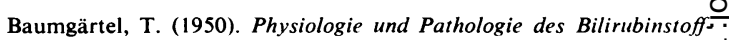
wechsels als Grundlagen der Ikterusforschung. Thieme, Stutt $\overrightarrow{7}$ gart.

Billing, B. H., and Lathe, G. H. (1956). Biochem. J., 63, 6P.

Bingold, K., and Stich, W. (1954). Ergeb. inn. Med. Kinderheilk., n.s. $5,707$.

Bungenberg de Jong, W. J. H. (1942). Ned. T. Geneesk., 86, 2405.

Drabkin, D. L. (1958). Thudichum, Chemist of the Brain. University of Pennsylvania Press, Philadelphia.

Ehrlich, P. (1901). Med. Woche, 1, 151.

Fischer, H. (1911). Hoppe-Seylers Z. physiol. Chem., 73, 204.

_ _ , Halbach, H., and Stern, A. (1935). Justus Liebigs Ann. Chem.; $519,254$.

_, and Libowitzky, N. (1939). Ibid., 258, 255.

- , and Meyer-Betz, F. (1911). Hoppe-Seylers Z. physiol. Chem., 75 O 232.

and Niemann. G. (1924). Ibid., 137, 293.

_ and Reindel, F. (1923). Ibid., 127, 299.

Fromholdt, G., and Nersessoff, N. (1912). Z. exp. Path. Ther., 11, 400:

Garrod,' A. E., and Hopkins, F. G. (1896). J. Physiol. (Lond.), 20; 112.

Gilbertsen, A. S., Bossenmaier, I., and Cardinal, R. (1962). Natur(은 (Lond.), 196, 141.

- Lowry, P. T., Hawkinson, V., and Watson, C. J. (1959). J. cline Invest., 38, 1166.

- , and Watson, C. J. (1962). Ibid., 41, 1041

Gray, C. H., Kulczycka, A., and Nicholson, D. C. (1961). J. Chem. Soc., p. 2276.

and Nicholson, D. C. (1957a). Nature (Lond.), 179, 264

- (1957b). Ibid., 180, 336.

(1958a). Ibid., 181, 483.

(1958b). J. chem. Soc., p. 3085.

_- and Nicolaus, R. A. (1958). Nature (Lond.), 181, 183.

, and Scott, J. J. (1958). Biochem. J., 71, 38.

Gregory, C. H., and Watson, C. J. (1962). J. Lab. clin. Med., In press

Gustafsson, B. E., and Lanke, L. S. (1960). J. exp. Med., 112, 975.

Hagen, P. S., and MacDonald, R. M. (1954). J. Lab. clin. Med., 44, 807.

Hopkins. F. G., and Garrod, A. E. (1898). J. Physiol. (Lond.), 22, 451. 응

Israels, L. G., Suderman, H. J., and Ritzmann, S. E. (1959). Amer. J.Q Med., 27, 693.

- - and Zipursky. A. (1962). Nature (Lond.), 193, 73.

Isselbacher, K. J., and McCarthy, E. A. (1959). J. clin. Invest.. 38, 645.马

Jaffé, M. (1868). Zbl. med. Wiss., 6, 241.

- (1869). Ibid., 7, 177.

James, G. W., and Abbott, L. D. Jr. (1959). J. clin. Invest.. 38. 1014

- - (1961a). Ibid. (abst.), 40, 1051

Jedlicka, V. (1930). Folia haemat. (Lpz.), 42, 359.

Kahán, de Z., and Kahán, A. (1959). Nature (Lond.), 183, 463.

Kämmerer, H., and Miller, R. (1922). Wien. klin. Wschr.. 35, 639.

Kay, J. T., Weimer, M., and Watson, C. J. (1963). J. Biol. Chem. in press.

L.air. J. F. Van, and Masius, J. B. (1871). Centralbl. med. Hissensch. 9. 369 .

Legge, J. W. (1949). Biochem. J., 44. 105.

Lemberg, R. (1955). J. and Proc. roy. Soc. New Sth Wales, 1954, 88, 114

, and Legge, J. W. (1949). Hematin Compounds and Bile Pigmem I Interscience, New York.

Lockwood, W. H., and Wyndham. R. A. (1938). Aust. J. exp. Biol. med. Sci., 16, 169

Le Nobel, C. (1887). Pflüger's Arch. ges. Physiol., 40, 501.

Lester, R., Ostrow, J. D., and Schmid, R. (1961). Nature (Lond.). 192. N 372 .

London. I. M., and West, R. (1950), J. biol. Chem., 184, 359.

_- _- Shemin, D., and Rittenberg, D. (1950). Ibid., 184, 351.

Lowry, P. T., Ziegler, N. R., Cardinal, R., and Watson, C. J. (1954). Ibid., 208, 543 .

McMaster, P. D., and Elman. R. (1925). J. exp. Med., 41. 513

- - (1926). Ibid., 43, 753 .

(1927). Ann. intern. Med., 1, 68.

MacMunn, C. A. (1880). Proc. roy. Soc., 31, 26.

(1889). J. Physiol. (Lond.), 10, 71.
Maier, V. C., and Schwarz, K. J. (1953). Schweiz. Rundschau Med.. $42,156$.

Maly, R. (1871). Ann. Chem. Pharm., 161, 368.

- (1872). Ibid., 163, 77

Müller, F. (1887). Z. klin. Med., 12, 45

Nakajima, H. (1958). Proc. Jap. Acad., 34, 712 
Neubauer, O. (1903). Münch. med. Wschr., 50, 1846.

Noro, T., (1951). Igaku Kenkyu, 21, 862.

Passini, F. (1922). Wien. klin. Wschr., 35, 217.

- and Czaczkes, J. (1923). Ibid., 36, 657.

Rudolph, H. (1952). Chemie und Klinik der Bilirubinreduktionsprodukte; Urobilin und Sterkobilin. Thieme, Leipzig.

Saillet, - (1897). Rev. méd. (Paris), 17, 109.

Sborov, V. M., Jay, A. R., and Watson, C. J. (1951). J. Lab. clin. Med., 37, 52.

Schmid, R. (1956). Science, 124, 76.

Schoenfield, L. J., Bollman, J. T. and Hoffman, H. N., II (1962). J. clin. Invest., 41, 133.

Schwartz, S., and Watson, C. J. (1942). Proc. Soc. exp. Biol. (N.Y.), 49, 643.

Siedel, W. (1957). Uber die Konstitution des D-Urobilins und Stercobilins. In Pathologie, Diagnostik und Therapie der Leberkrankheiten (Viertes Freiburger Symposium). Springer, Berlin.

- , and Meier, E. (1936). Hoppe-Seylers Z. physiol. Chem., 242, 101. Pölnitz, W. von, and Eisenreich, F. (1947). Naturwissenschaften, 34, 314.

—, Stich, W., and Eisenreich, F. (1948). Ibid., 35, 316.

Singleton, J. W., and Laster, L. (1961). Fed. Proc., 20, 247.

Sjöstrand, T. (1949). Scand. J. clin. Lab. Invest., 1, 201.

Stadelmann, E. (1891). Der Icterus und seine verschiedenen Formen. Enke, Stuttgart.

Städeler, G. (1864). Ann. Chem. Pharm., 132, 323.

Stich, W. (1946). Dtsch. med. Wschr., 71, 137.

- (1948). Klin. Wschr.. 26, 365.

Tarchanoff, J. F. (1874). Pfügers Arch. ges. Physiol., 9, 53.

Terwen, A. J. L. (1925). Dtsch. Arch. klin. Med., 149, 72.

Thudichum, J. L. W. (1858). Pathology of the Urine. Churchill. London.

- (1864). Brit. med. J., 2, 509.

(1897). Virchows Arch. path. Anat., 150, 586.

Virchow, R. (1847). Ibid., 1, 379.

Walzel, P., and Weltmann, O. (1924). Mitt. Grenzgeb. Med. Chir., 37, 437.

Watson, C. J. (1932a). Hoppe-Seylers Z. physiol. Chem., 204, 57.

- (1932b). Ibid., 208, 101.

- (1933a). Ibid., 221, 145.
Watson, C. J. (1933b). Proc. Soc. exp. Biol. (N.Y.), 30, 1207.

- (1934). J. biol. Chem., 105, 469.

- (1935a). Hoppe-Seylers Z. physiol. Chem., 233, 39.

- (1935b). Proc. Soc. exp. Biol. (N.Y.), 32, 1508.

- (1938). In Handbook of Hematology, ed. H. Downey, vol. 4, p. 2447. Hoeber, New York.

(1950). In The Harvey Lectures, 1948-1949, Series XLIV, p. 41. Thomas, Springfield, Illinois. (1953). J. biol. Chem., 200, 691

(1956). Minn. Med., 39, 294, 403, 467.

(1958). Fed. Proc., 17, 331.

-, Campbell, M., and Lowry, P. T. (1958). Proc. Soc. exp. Biol. (N.Y.), 98, 707.

—, and Jones, O. P. (1936). Univ. Minn. med. Bull., 7, 339. and Lowry, P. T. (1956). J. biol. Chem., 218, 633.

$\longrightarrow$, Collins, S., Graham, A., and Ziegler, N. R. (1954). Trans. Ass. Amer. Phycns., 67, 242.

- , and Schwartz, S. (1942). Proc. Soc. exp. Biol. (N.Y.), 49, 636.

—, and Weimer, Mary (1959). J. Lab. clin. Med., 54, 1. 787.

- - (1963). J. Biol. Chem. In press.

Yamaguchi, M., Nakajima, H., and Yamaoka, K. (1961). Proc. Jap. Acad., 37, 584.

\section{ADDENDUM}

As pointed out by Gray and Nicholson, the bislactam formulation of i-urobilin, as in Fig. 1, implies potential molecular asymmetry. However, racemization via the tautomeric bis-lactim form may be so rapid as to preclude the isolation of enantiomeric forms of $i$-urobilin. It may be noted that Siedel's formulation of d-urobilin was lactim rather than bis-lactam, but only in respect to the asymmetric centre. 